\title{
Distribution and Lateral Mobility of Glycine Receptors on Cultured Spinal Cord Neurons
}

\author{
Yogambal Srinivasan, ${ }^{1}$ Anthony P. Guzikowski, ${ }^{2}$ Richard P. Haugland, ${ }^{2}$ and Kimon J. Angelides ${ }^{1}$ \\ 'Department of Molecular Physiology and Biophysics, Baylor College of Medicine, Houston, Texas 77030, and \\ 2Molecular Probes, Inc., Eugene, Oregon 97402
}

\begin{abstract}
Strychnine is one of the most potent antagonists of glycinemediated inhibitory conductances in the mammalian spinal cord. In order to examine the distribution of glycine receptors (GlyRs) on neuronal cells, 2 novel fluorescent strychnine derivatives were synthesized and characterized chemically, spectroscopically, and biologically. Both compounds retain their biological activity after derivatization and are potent inhibitors of ${ }^{3} \mathrm{H}$-strychnine binding to bovine spinal cord membranes and membranes from rat spinal cord cultures. Using these fluorescent strychnine analogs, the cellular distribution and lateral mobility of GlyRs on cultured rat spinal cord neurons were studied by digital fluorescence imaging and photobleach recovery microscopy. On these neurons, even in the absence of observable synaptic contact and early in development GlyRs are predominantly localized to cell bodies with sparse labeling of neuritic processes. Although GlyRs are confined to the neuronal cell body, approximately $50 \%$ of the receptors are very mobile, with lateral diffusion coefficients of $1.15 \pm 0.05 \times 10^{-9} \mathrm{~cm}^{2} / \mathrm{sec}$, a value which is characteristic of unrestricted protein lateral diffusion. However, the remaining fraction of these receptors are immobile on the neuronal cell body. More than $70 \%$ of the GlyRs distributed on neuronal processes are immobile, while $\mathbf{3 0} \%$ are laterally mobile, with diffusion rates of $\mathbf{5 . 5 0}$ $\pm 0.1 \times 10^{-10} \mathrm{~cm}^{2} / \mathrm{sec}$. The results indicate that even early in development GlyRs are expressed and segregated to the cell body, where they are confined within a domain that restricts their redistribution.
\end{abstract}

Glycine is the major inhibitory transmitter in the mammalian spinal cord and other regions of the central nervous system (Krnjevic, 1974). Binding of this amino acid to its specific receptor increases the chloride conductances of the neuronal membrane and thus produces hyperpolarization, i.e., inhibition of the postsynaptic neuron (Coombs et al., 1955). The alkaloid strychnine selectively antagonizes glycine-mediated responses, and the acquisition of glycine-displaceable high-affinity ${ }^{3} \mathrm{H}$ -

Received July 10, 1989; revised Oct. 16, 1989; accepted Oct. 17, 1989.

This work was supported by grants from NIH (NS 24606) and the Muscular Dystrophy Association to K.J.A., Baylor Research Support Grant to Y.S. and R43 GM37347-01 to R.P.H. K.J.A. is the recipient of a Research Career Development Award from the NIH (NS 01218). We wish to thank Peter Haroldsen and Simon Gaskell of the Department of Medicine for the mass spectra and J. Kirkpatrick for use of the digital image-analysis equipment.

Correspondence should be addressed to Kimon J. Angelides, Department of Molecular Physiology and Biophysics, Baylor College of Medicine, One Baylor Plaza, Houston, TX 77030.

Copyright (C) 1990 Society for Neuroscience $0270-6474 / 90 / 030985-11 \$ 02.00 / 0$ strychnine hinding has been used as an indicator for the maturation of the glycine receptor (GlyR) (Young and Snyder, 1973; Snyder and Bennett, 1976; Becker et al., 1988). The high-affinity and selectivity of strychnine for the GlyR has also been used to isolate and biochemically purify the adult GlyR by affinity chromatography on strychnine-affigel (Pfeiffer et al., 1982). The purified GlyR is composed of 3 polypeptides of molecular mass 48 , 58 , and $93 \mathrm{kDa}$ (Graham et al., 1981, 1985), where the $48 \mathrm{kDa}$ subunit contains both the strychnine binding site (Pfeiffer et al., 1982) and the ability to express glycine-mediated $\mathrm{Cl}^{-}$conductances after injection of its mRNA in oocytes (Schmeiden et al., 1989). The primary structure of the $48 \mathrm{kDa}$ component obtained from its cDNA indicates that this polypeptide belongs to the ligand-gated ion channel superfamily, which includes the nicotinic ACh reccptor and the GABA receptor (Grenningloh et al., 1987). The role of the $58 \mathrm{kDa}$ polypeptide is not known, but it shows significant homology to the $48 \mathrm{kDa}$ subunit. Thus far, no functional role has been ascribed to the $93 \mathrm{kDa}$ component; it appears to be a peripheral protein that can be removed from the GlyR complex and has been postulated to be a cytoskeleton-associated protein (Schmitt et al., 1987).

Despite information on the structure and function of GlyRs, little is known about their distribution and expression and the placement of their glycinergic inhibitory synaptic inputs during development. Direct quantitative autoradiography using ${ }^{3} \mathrm{H}$ strychnine (Zarbin et al., 1981), as well as immunocytochemical methods utilizing monoclonal antibodies (mAbs) to GlyR subunits (Triller et al., 1985; Araki et al., 1988; Seitanidou et al., 1988) or anti-glycine antibodies (van den Pol and Gorcs, 1988), have been used to study GlyR distribution in the CNS. Such studies have shown a good correspondence between loci of high GlyR densities and regions where strychnine and glycine are electrophysiologically active. Though informative on the regional localization and specificity of these receptors in the mammalian CNS, these studies still provide only static views of receptor distribution at the single-cell level. In order to explore the dynamics of GlyR distribution and the elements that maintain this distribution on living nerve cell surfaces, we have synthesized 2 fluorescent strychnine analogs and used these derivatives to examine the topography, distribution, and lateral mobility of GlyRs on spinal cord neurons in culture by fluorescence digital imaging and photobleach recovery.

\section{Materials and Methods}

Materials

Strychnine nitrate was obtained from Sigma Chemical Co. ${ }^{3} \mathrm{H}$-strychnine (specific activity, $30 \mathrm{Ci} / \mathrm{mmol}$ ) was from Amersham. NBD-hexanoic acid and BODIPY-acetic acid (boron dipyrromethene acetate, a 


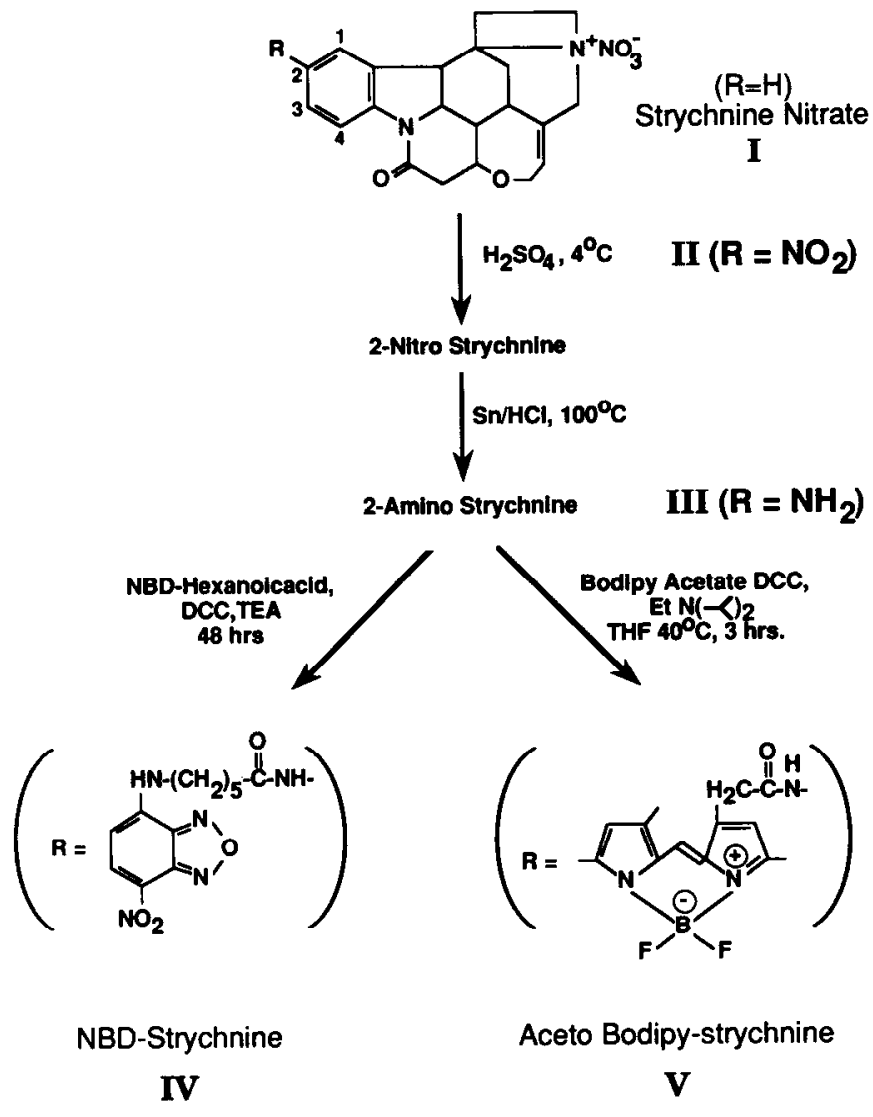

Figure 1. Scheme for synthesis of fluorescent strychnine derivatives. Details of synthesis are described in Materials and Methods.

trademark of Molecular Probes, Inc.) were from Molecular Probes (Eugene, OR), tetramethylrhodamine-wheat germ agglutinin (TmRh-WGA) was from Vector Laboratories and tetramethylrhodamine-phosphatidylethanolamine (TmRh-PE) was obtained from Avanti Polar Lipids. Eagle's minimal medium (MEM) and tissue culture reagents were from Sigma or Gibco.

\section{Methods}

It is well documented that after derivatization of the aromatic ring, strychnine [Fig. 1 (I)] retains full biological activity, while any modifications of the amide nitrogen or oxepin oxygen leads to inactive molecules. Thus, in the present study, all modifications were carried out on the aromatic ring of strychnine. The synthetic intermediates, 2-nitrostrychnine (II) and 2-amino-strychnine (III) are potent inhibitors of ${ }^{3} \mathrm{H}$ strychnine binding to bovine spinal cord membranes (Mackerer et al., 1977). Since 2-amino-strychnine is biologically active, 2 different fluorescent derivatives were synthesized from this intermediate where 6 carbon (NBD-strychnine) and 2 carbon (BODIPY-strychnine) spacer arms were inserted between strychnine and the fluorescent moiety.

Synthesis of 2-amino-strychnine. To prepare 2-amino-strychnine, strychnine was converted to the 2-nitro derivative from strychnine nitrate as described (Rosenmund, 1961). Strychnine nitrate $(4 \mathrm{gm})$ was added slowly with stirring into a mixture of $23 \mathrm{ml}$ of concentrated sulfuric acid and $9 \mathrm{ml} \mathrm{H}_{2} \mathrm{O}$ cooled to $4^{\circ} \mathrm{C}$. Stirring was continued for $60 \mathrm{~min}$ at $12^{\circ} \mathrm{C}$. The solution was poured into ice and neutralized to pH 8.0 with ammonium hydroxide. The pale yellow solid was filtered (80\% yield) and dried. $\mathrm{R}_{\mathrm{f}}$ in $\mathrm{CHCl}_{3}: \mathrm{CH}_{3} \mathrm{OH}(4: 1), 0.46$. Chemical shift in solvent $\left.\mathrm{CDCl}_{3}: \mathrm{H}(4) \mathrm{d} 8 \cdot 3 \delta ; \mathrm{H}(1) \mathrm{s} 7 \cdot 7 \delta ; \mathrm{H}(3) \mathrm{d} 7 \cdot 5 \delta\right)$. To obtain 2-amino-strychnine, the 2-nitro group was reduced with granulated tin. 2-Nitro-strychnine $(3 \mathrm{gm})$ was dissolved in $85 \mathrm{ml}$ of $3 \mathrm{~N} \mathrm{HCl}$ and refluxed at $100^{\circ} \mathrm{C}$ in a water bath with $20 \mathrm{gm} \mathrm{Sn}$ granules for $2 \mathrm{hr}$, during which time the solution decolorized. Sn granules were removed, washed with $10 \mathrm{ml}$ of $3 \mathrm{~N} \mathrm{HCl}$, the wash pooled with the mother liquor, and the combined solutions refrigerated overnight. To obtain the free base,
A.

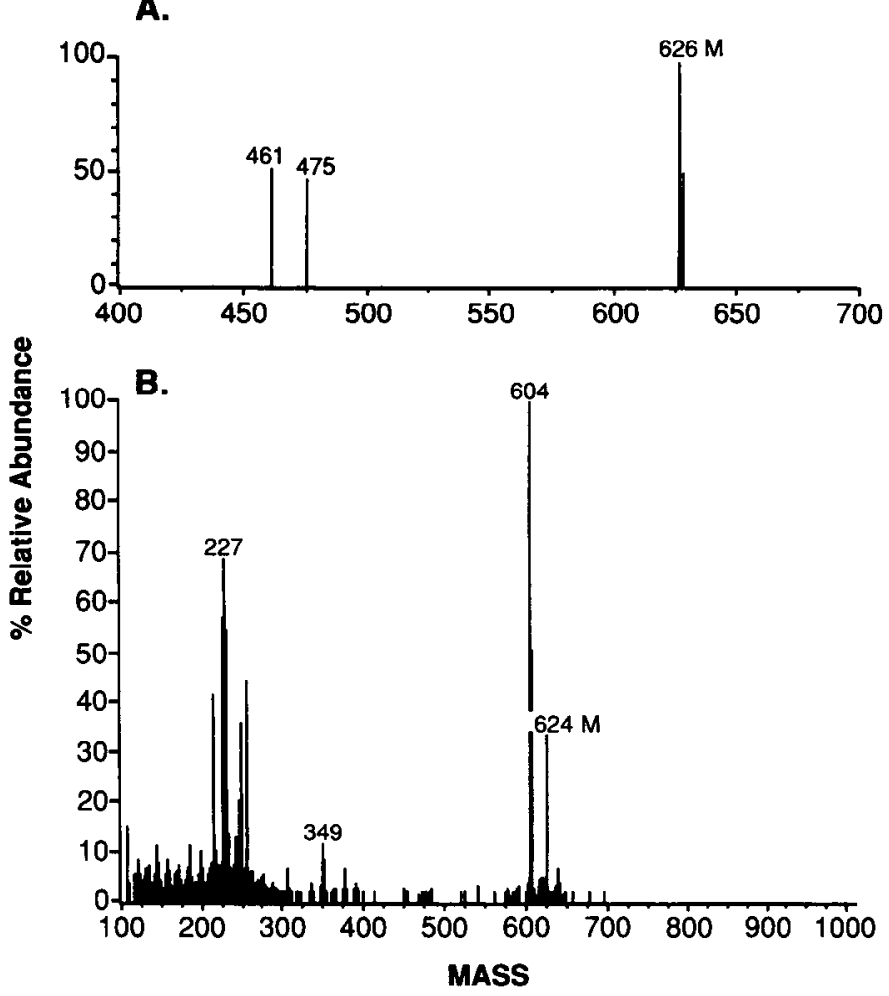

Figure 2. Mass spectra of $(A)$ NBD-strychnine and $(B)$ BODIPYstrychnine. $M$ denotes the molecular ion peak.

the precipitated Sn double salt of the amine was filtered and dried (4.5 $\mathrm{gm}$ ), then redissolved in $400 \mathrm{ml}$ of $0.75 \mathrm{~N} \mathrm{HCl}$ and heated. $\mathrm{H}_{2} \mathrm{~S}$ gas was passed through the solution to precipitate $\mathrm{Sn}^{2+}$ as the sulfide. The solution was filtered to remove the SnS, the filtrate ncutralized to $\mathrm{pH} 8.0$ with $\mathrm{NH}_{4} \mathrm{OH}$, and refrigerated overnight. Crystals of 2-amino-strychnine that formed were collected and dried under vacuum (yield $2 \mathrm{gm}$ ). 2-Amino-strychnine, identified first by its intense purple staining with ninhydrin spray reagent, was further purified by preparative thin-layer chromatography on $1.0 \mathrm{~mm}$ silica gel $\mathrm{G}$ plates with $\mathrm{CHCl}_{3}: \mathrm{CH}_{3} \mathrm{OH}(4$ 1); Rf 0.08. The 2-amino-strychnine was eluted from these preparative plates with methanol and dried. After chemical verification by proton NMR and mass spectral analysis, the material was used directly for synthesis of the fluorescent derivatives. Chemical shifts in $\mathrm{CDCl}_{3} \mathrm{H}(4) \mathrm{d}$ $8 \cdot 2 \delta, \mathrm{H}(1) \mathrm{s} 7 \cdot 5, \mathrm{H}(3) \mathrm{d} 7 \cdot 3 \delta, \delta 6 \cdot 7(2 \mathrm{H})$.

Fluorescent strychnine derivatives. Fluorescent derivatives were synthesized by coupling a fluorescent acid to the aromatic primary amine of 2-amino-strychnine.

$N B D$-strychnine. 2 -Amino-strychnine $30 \mathrm{mg}(85 \mu \mathrm{mol})$ was dissolved in freshly distilled dry dichloromethane $(0.5 \mathrm{ml})$ with $30 \mathrm{mg}(100 \mu \mathrm{mol})$ of NBD-hexanoic acid. Triethylamine $(100 \mu \mathrm{l})$ and dicyclohexylcarbodiimide $300 \mu$ l of a $0.5 \mathrm{M}$ solution $(145 \mu \mathrm{mol})$ in dichloromethane were added. Because coupling of carboxylic acids to aromatic amines is slow, the reaction was carried out for $2 \mathrm{~d}$ in dim light with stirring; aliquots were removed to examine the progress of the reaction. After 2 $\mathrm{d}$, the reaction was complete. The dicyclohexylurea that resulted from the coupling was removed by centrifugation and the supernatant carefully separated. The product, 2-((6-) 7-nitro-4-benzoxadiazolyl)amino)hexanoyl) amino strychnine, was purified by preparative thinlayer chromatography, $\mathrm{CHCl}_{3}: \mathrm{CH}_{3} \mathrm{OH}(4: 1)(\mathrm{R} f 0.22)$. The fluorescent derivative was eluted from the plates with methanol, dried, and flashevaporated, and the structure verified chemically (see below). The yield was $40 \mathrm{mg}(60 \%)$.

BODIPY-strychnine. Similar dicyclohexylcarbodiimide coupling chemistry was used to couple the BODIPY chromophore. To synthesize 2-(BODIPY-acetylamino)-strychnine (BODIPY-strychnine), $35 \mathrm{mg}$ 2-amino-strychnine $(85 \mu \mathrm{mol})$ was reacted with $28 \mathrm{mg}(100 \mu \mathrm{mol})$ of BODIPY-acetic acid, $30 \mathrm{mg}$ dicyclohexylcarbodiimide $(145 \mu \mathrm{mol})$, and $12.9 \mathrm{mg}(100 \mu \mathrm{mol})$ dissopropyl ethyl amine at $40^{\circ} \mathrm{C}$ in $0.5 \mathrm{ml}$ of dry 

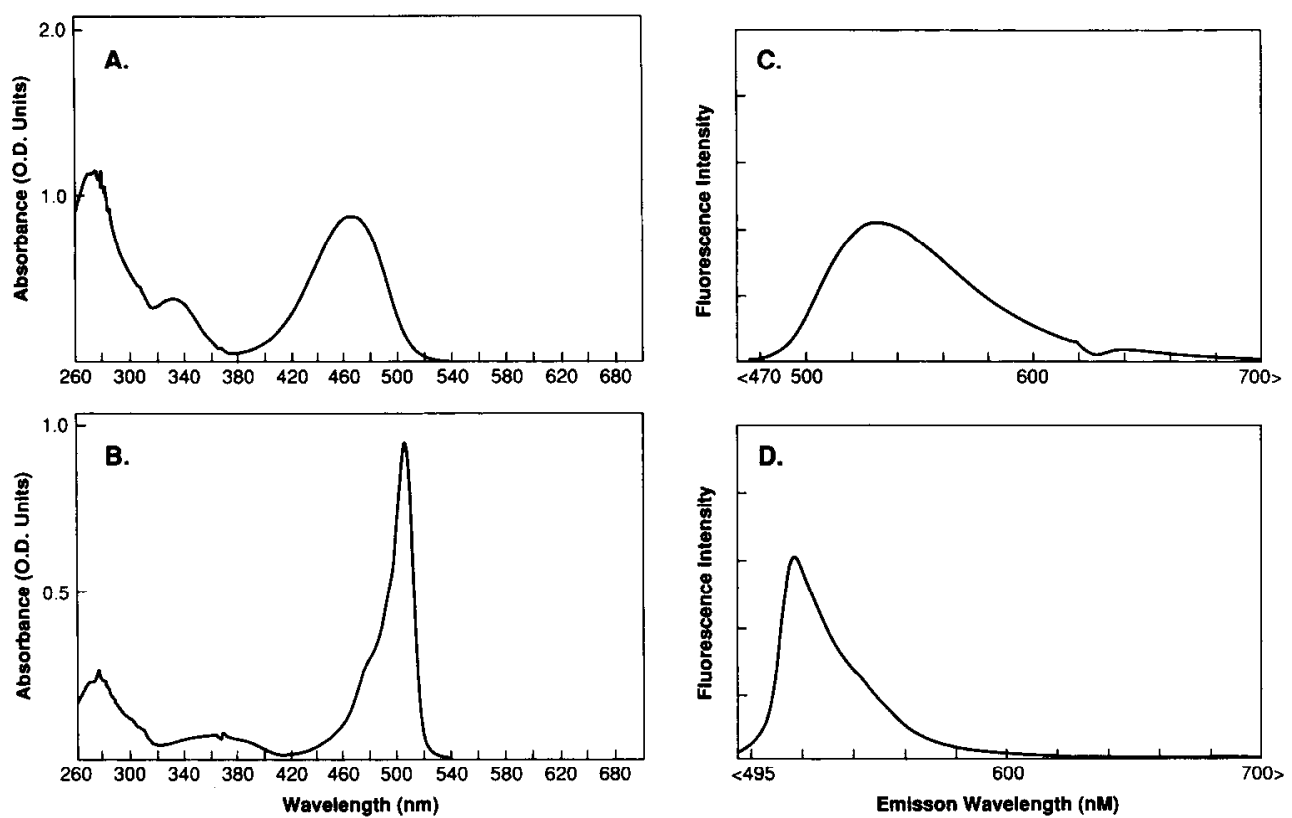

Figure 3. Spectral characteristics of NBD-strychnine and BODIPY-strychnine: $A$ and $B$, absorption spectra of NBD-strychnine and BODIPY-strychnine; $C$ and $D$, fluorescence emission spectra of NBD-strychnine (excitation at $460 \mathrm{~nm}$ ) and BODIPY-strychnine (excitation at $510 \mathrm{~nm}$ ). Spectra were recorded using methanol as solvent. tetrahydrofuran for $3 \mathrm{hr}$. The precipitated dicyclohexylurea was filtered and the supernatant purified on preparative silica gel plates using $\mathrm{CHCl}_{3}$ : $\mathrm{CH}_{3} \mathrm{OH}(4: 1)(\mathrm{R} f 0.32)$.

The chemical structure of synthetic intermediates and fluorescent derivatives were characterized by using a $200 \mathrm{MHz}$ proton NMR Varian Spectrometer and by mass spectrometry on a VG-ZAB-SEQ hybrid tandem mass spectrometer operated in the fast atom bombardment mode.

The mass spectrum of the final product, NBD-strychnine (Fig. 2A) shows a molecular ion peak at $m / e 626$ corresponding exactly to its predicted mass of 626 and daughter fragments at $m / e 475$ corresponding to

$$
\stackrel{\stackrel{\mathrm{O}}{\|}}{+\left(\mathrm{N}\left(\mathrm{CH}_{2}\right)_{5}-\stackrel{\mathrm{C}}{-}-\mathrm{N}-\text { strychnine }\right)}
$$

and 461 corresponding to

$$
\begin{gathered}
\mathrm{O} \\
+\left(\left(\mathrm{CH}_{2}\right)_{5}-\stackrel{\mathrm{C}}{\mathrm{C}}-\mathrm{NH}-\text { strychnine }\right) .
\end{gathered}
$$

The mass spectrum of BODIPY-strychnine (Fig. $2 B$ ) also shows a molccular ion peak at $m / e 624$ (predicted molecular weight 624). Loss of HF gives $m / e 604$ and loss of the NBD-hexanoate peak $m / e 349$ corresponding to ${ }^{+}$(NH-strychnine). The NMR spectrum of BODIPYstrychnine confirms the structure shown, chemical shifts in $\mathrm{CDCl}_{3}: \mathrm{H}(4) \mathrm{d}$ $8 \delta, \mathrm{H}(1) \mathrm{s} 7 \cdot 7 \delta, \mathrm{H}(3) \mathrm{d} 7 \cdot 5 \delta$ and the olefinic proton of oxepin ring at $6 \delta(\mathrm{t})$. The 3 olefinic protons of the BODIPY ring structures have chemical shifts at $6 \cdot 2 \delta(2 \mathrm{H})$ s and $6 \cdot 4 \delta(1 \mathrm{H}) \mathrm{s}$.

Fluorescence excitation and emission spectra of the fluorescent strychnine derivatives were obtained on a SLM $8000 \mathrm{C}$ fluorescence spectrometer, and absorption spectra were recorded on a Cary 210 spectrophotometer. The NBD-strychnine and BODIPY-strychnine were characterized by absorption (Fig. 3, A,B) and fluorescence emission spectroscopy (Fig. 3, $C, D$ ). NBD-strychnine had an excitation maximum at $465 \mathrm{~nm}$ and a broad emission maximum centered at $530 \mathrm{~nm}$. The BODIPY-strychnine had an excitation maximum at $505 \mathrm{~nm}$ and a sharp emission maximum at $525 \mathrm{~nm}$. The newly developed fluorescent dipyrromethene borondifluoride (BODIPY) dyes have outstanding spectral properties. These probes have similar excitation and emission spectra to fluorescein but have significantly improved photostability, higher quantum yield, and low pH sensitivity (Haugland and Kang, 1988).
Preparation of membranes. Bovine spinal cord membranes were prepared as described (Graham et al., 1985). Spinal cords were obtained fresh from a local slaughterhouse, stripped of meninges, quick frozen in liquid $\mathrm{N}_{2}$, and stored at $-70^{\circ} \mathrm{C}$ for no longer than 2 months. Membranes were prepared from frozen spinal cord and stored in $25 \mathrm{~mm}$ potassium phosphate $(\mathrm{pH} \mathrm{7.4)} \mathrm{containing} 1 \mathrm{M} \mathrm{KCl}$ and a protease inhibitor cocktail containing $100 \mu \mathrm{M}$ phenylmethane sulfonyl fluoride, $100 \mu \mathrm{M}$ benzethonium chloride, $16 \mathrm{milliunits} / \mathrm{ml}$ aprotinin, and $0.2 \mathrm{mM}$ EDTA. A crude membrane fraction from cultured spinal cord neurons ( 50 dishes and 4 weeks in culture) was obtained by removing the culture medium from the dishes and rinsing 2-3 times with ice-cold MEM without phenol red. The cells were lysed by hypotonic lysis with $10 \mathrm{mM}$ potassium phosphate, $0.2 \mathrm{~mm}$ EDTA, $\mathrm{pH} 7.4$, containing the protease inhibitor cocktail described above, scraped off the culture dish, and centrifuged at $14,000 \mathrm{rpm}$ for $5 \mathrm{~min}$ at $4^{\circ} \mathrm{C}$ in an Eppendorf centrifuge. The pelleted material was homogenized in $200 \mathrm{~mm} \mathrm{KCl}, 25 \mathrm{~mm}$ phosphate, $\mathrm{pH} 7.4$, with protease inhibitors and centrifuged at $14,000 \mathrm{rpm}$ for $5 \mathrm{~min}$ at $4^{\circ} \mathrm{C}$. Protein was determined by the method of Bradford (1976).

Binding assays. Membranes ( $1 \mathrm{mg}$ protein) were incubated for $60 \mathrm{~min}$ at $4^{\circ} \mathrm{C}$ in $25 \mathrm{~mm}$ potassium phosphate, $200 \mathrm{~mm} \mathrm{KCl}$ (buffer A), $10 \mathrm{nM}$ ${ }^{3} \mathrm{H}$-strychnine, and varying concentrations of competing ligands. Nonspecific binding was determined by competition with $100 \mu \mathrm{M}$ strychnine. The reaction was terminated by rapid dilution with $3 \mathrm{ml}$ of ice-cold buffer A, filtering on GF/B filters, with two $3 \mathrm{ml}$ washes with the same buffer. For ${ }^{3} \mathrm{H}$-strychnine binding to membranes from cultured cells 100 $\mu \mathrm{g}$ protein was used per assay. Incubations and filtrations were as described for spinal cord membranes.

Spinal cord neuronal cultures. Embryonic rat spinal cord neurons were cultured using a modified procedure of Bottenstein and Sato (1979) and Angelides et al. (1988) from $15 \mathrm{~d}$ gestational embryos using serum-free medium, without antibiotics or inhibitory neurotransmitter substances. Spinal cords were dissected and dissociated using a combination of mechanical and mild enzymatic treatment with a neutral protease, dispase for $1 \mathrm{hr}$ at $37^{\circ} \mathrm{C}$. The cells were plated onto $35 \mathrm{~mm}$ dishes containing $1 \mathrm{~mm}$ glass coverslips coated with poly-D-lysine at a density of $1 \times 10^{6}$ cells/dish in Eagle's minimal medium (MEM) supplemented with $5 \mathrm{gm} /$ liter glucose and $2.2 \mathrm{gm} /$ liter sodium bicarbonate and containing $10 \%$ horse scrum and $10 \%$ fetal bovine serum. The cells were grown in this medium for $24 \mathrm{hr}$ and then transferred to serum-free MEM without antibiotics containing the following supplements: $100 \mu \mathrm{g} / \mathrm{ml}$ transferrin, $5 \mu \mathrm{g} / \mathrm{ml}$ insulin, $30 \mathrm{nM}$ sodium arsenite, $20 \mathrm{nM}$ progesterone, $100 \mu \mathrm{M}$ putrescine, and $2 \mathrm{~mm}$ pyruvate. Approximately $5 \%$ of the cells in the culture were glia as assessed immunocytochemically with antibodies specific for glial fibrillary acidic protein. Spinal cord cell cultures were 


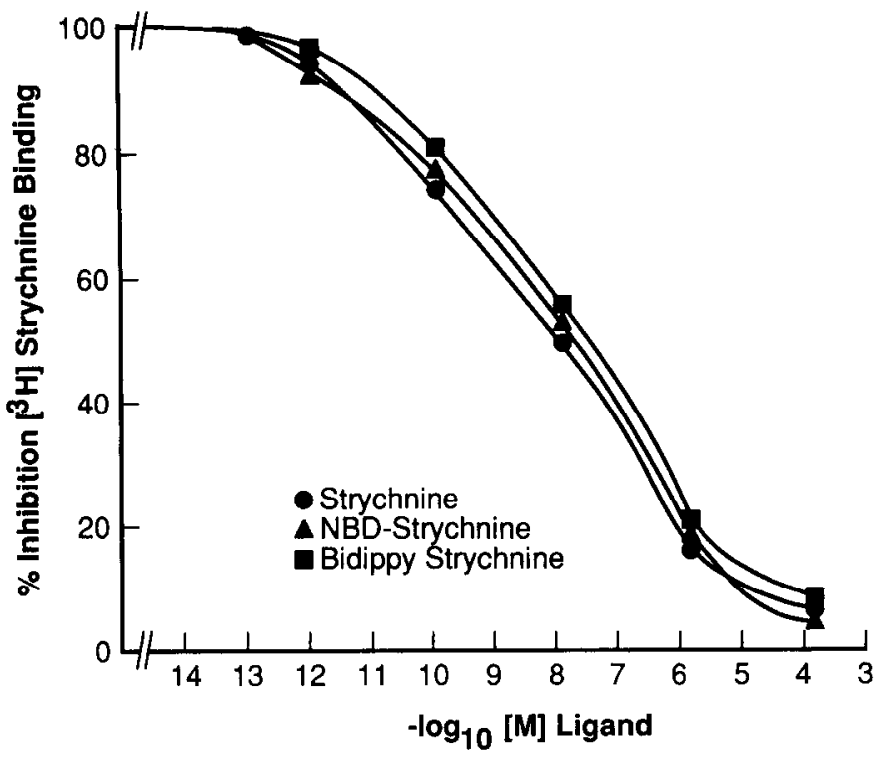

Figure 4. Displacement of ${ }^{3} \mathrm{H}$-strychnine binding from bovine spinal cord membranes by strychnine nitrate NBD-strychnine and BODIPYstrychnine. Experimental details are explained in Materials and Methods. Displacement by strychnine nitrate $(\bullet)$, NBD-strychnine $(\boldsymbol{\Delta})$, and BODIPY-strychnine $(\square)$ are indicated. $K$ ivalues were calculated by the method of Cheng and Prusoff (1973).

studied after 3-6 weeks of development in vitro, at which time maturation of the neurons and density of ${ }^{3} \mathrm{H}$-strychnine binding siles were at a maximum. The developmental stage and differentiation of these neurons has been characterized by the expression and locale of the neurotilament proteins (Angelıdes et al., 1988). Cells developed with the characteristic morphology described earlier for spinal cord neurons (Nelson et al., 1976). Although identification is based largely on morphology, a large proportion corresponds to interneurons with few large motoneurons. The morphology and electrophysiology of spinal cord neurons in tissue culture have been studied in detail (Nelson et al., 1977; Jackson et al., 1982), and these cells exhibit strong inhibitory postsynaptic potentials in response to externally applied glycine.

Fluorescence digital imaging and photobleach recovery (FPR) microscopy. Spinal cord neurons on poly-D-lysine coverslips were washed 3 times at 2 min intervals with $2 \mathrm{ml}$ each of MEM containing $10 \mathrm{~mm}$ HEPES and $13.75 \mathrm{gm} /$ liter glucose, $\mathrm{pH} 7.4$, to remove the culture medium containing phenol red. For imaging or FPR, cells were incubated with $10 \mathrm{~nm}$ BODIPY-strychnine. Labeling and washing of cells were carried out under dim light. After $15 \mathrm{~min}$ at $25^{\circ} \mathrm{C}$, the cells were washed twice with $2 \mathrm{ml}$ of medium and used immediately. Nonspecific binding on the same field of cells was measured by displacement of the fluorescent strychnine with $100 \mu \mathrm{M}$ strychnine nitrate with a $30 \mathrm{~min}$ incubation at $27^{\circ} \mathrm{C}$. Nonspecific images were obtained using identical optical conditions.

Fluorescent images of the labeled cells were obtained on line with a Hamamatsu VIM photon-counting camera mounted onto a Zeiss Photomicroscope III and through a $63 \times 1.2$ numerical aperture waterimmersion lens placed directly in the culture dish. An attenuated laser beam $(2 \mu \mathrm{W})$ of a $4-\mathrm{W}$ argon-ion laser, tuned to $488 \mathrm{~nm}$, served as the illumination source, where the beam was dispersed by a diffusion lens. The intensifier of the camera was operated in the photon-counting mode.
For rhodamine-labeled compounds, the laser was tuned to $514 \mathrm{~nm}$.

Sets of images were collected in real time; a phase image of the cell was obtained first, followed by acquisition of the fluorescent image. A background image was obtained under identical optical conditions on an area devoid of cells. After sampling several cells in an area, to measure the contribution of nonspecific binding of BODIPY-strychnine to the image, $100 \mu \mathrm{M}$ strychnine nitrate in MEM was added to the cultures on the microscope stage, incubated with cells for $30 \mathrm{~min}$ at room temperature, the same cells from which the specific images were obtained were relocated, and images were recorded. The fluorescent images of the total and nonspecitic were registered according to the phase images and displayed.

Lateral diffusion coefficients $\left(D_{\mathrm{L}}\right)$ and mobile fraction, $f$, of fluorescently labeled receptors were measured by the spot photobleaching technique using the apparatus described (Axelrod et al., 1976; Henis and F.lson, 1981; Angelides et al., 1988). The monitoring argon-ion laser $488 \mathrm{~nm}(5 \mu \mathrm{W})$ was focused through the microscope to a Gaussian radius of $1.2 \mu \mathrm{m}(63 \times$ objective $)$. The illuminated region was bleached by a brief $10-200 \mathrm{msec}$ laser pulse $(5 \mathrm{~mW})$ bleaching $\sim 60 \%$ of the fluorescence. The time course of the fluorescence recovery was followed using the attenuated monitoring beam. The lateral diffusion coefficient and mobile fraction were determined by curve-fitting procedures (Angelides et al., 1988). Diffusion coefficients, $D_{L}$ (in $\mathrm{cm}^{2} / \mathrm{sec}$ ) were obtained from $\omega^{2} / 4 \tau_{\mathrm{D}}$, in which $\omega$ is the $e^{-2}$ radius of the beam profile and $\tau_{\mathrm{D}}$ is the half-time for recovery. Incomplete recovery of the fluorescence on the time scale of the experiments was interpreted as an immobile fraction of fluorophores (D $<1.0 \times 10^{-12} \mathrm{~cm}^{2} / \mathrm{sec}$ ). Appropriate controls for the specificity of cell labeling and nonspecific fluorescence were performed by measuring areas devoid of cells, on fibroblasts that formed a confluent monolayer in some cultures, or on neurons treated with 100 $\mu \mathrm{M}$ strychnine nitrate for $30 \mathrm{~min}$ at room temperature. Both fibroblasts and non-neuronal cells had negligible fluorescence; $<5 \%$ of the fluorescence was observed on fibroblasts compared with BODIPY-strychnine-labeled neurons. A large number of FPR measurements $(20-50)$ was performed in order to statistically analyze and evaluate the differences in measurement between various regions of the neuronal surface.

\section{Results}

Chemical analyses clearly identify the structures given in Figure 1, as shown in Figures 2 and 3 and discussed in detail in Materials and Methods. The 2 fluorescent derivatives were also assessed for their retention of biological activity by competitive displacement of ${ }^{3} \mathrm{H}$-strychnine binding to bovine spinal cord membranes (Fig. 4). Bovine spinal cord membranes have 0.25 $\mathrm{pmol} / \mathrm{mg}$ of specific ${ }^{3} \mathrm{H}$-strychnine binding sites, and glycine at a concentration of $1 \mathrm{~mm}$ quantitatively displaces $\geq 80 \%$ of the ${ }^{3} \mathrm{H}$-strychnine binding. The displacement curves for both BODIPY and NBD-strychnine indicate that both compounds retain the high affinity of the parent compound and are potent antagonists of ${ }^{3} \mathrm{H}$-strychnine binding. The calculated $K_{i}$ values for NBD-strychnine and BODIPY-strychnine are 12 and $14 \mathrm{~nm}$, respectively, compared with a $K_{d}$ for ${ }^{3} \mathrm{H}$-strychnine of $10.2 \mathrm{~nm}$. These results show that derivatization has little, if any, effect on the equilibrium binding of strychnine to its receptor site on the GlyR. The nonspecific binding of the fluorescent compounds also remained low, as it is for strychnine and did not exceed $10 \%$ for BODIPY strychnine or $12 \%$ for NBD-strychnine. In addition, both compounds are potent inhibitors of ${ }^{3} \mathrm{H}$-strychnine binding to membranes prepared from cultured spinal cord

Figure 5. Fluorescence labeling of GlyRs on cultured spinal cord neurons by BODIPY-strychnine. Details are described in Materials and Methods. $A$, Phase-contrast micrograph of the preparation on a substratum of non-neuronal cells. $B$, Fluorescent image after labeling with $10 \mathrm{nM}$ BODIPYstrychnine. $C$, Same cells as in $A$ and $B$, but after displacement of the BODIPY-strychnine with $100 \mu \mathrm{M}$ strychnine nitrate in MEM. The solid white arrow indicates position of cell. $D$, The specific labeling to the cells with relative intensities shown in color. The fluorescent image was accumulated for $10 \mathrm{sec}$. The cell indicated by solid black arrow was out of the plane of focus and thus no fluorescence appears associated with this cell. An additional verification of the specificity of the labeling is also seen in images where fluorescence from cells forming the substratum consisting of fibroblasts and glia is negligible. 


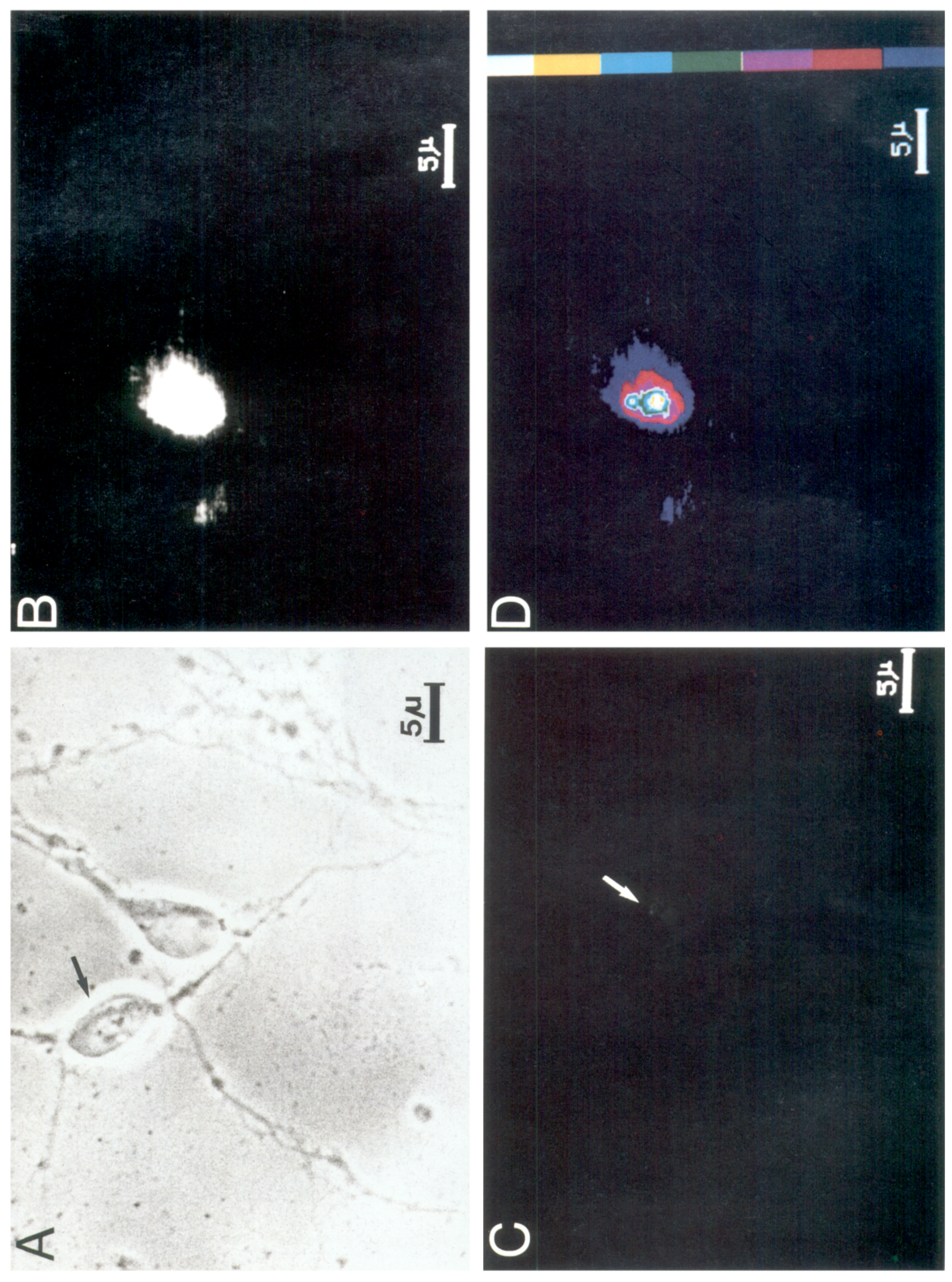



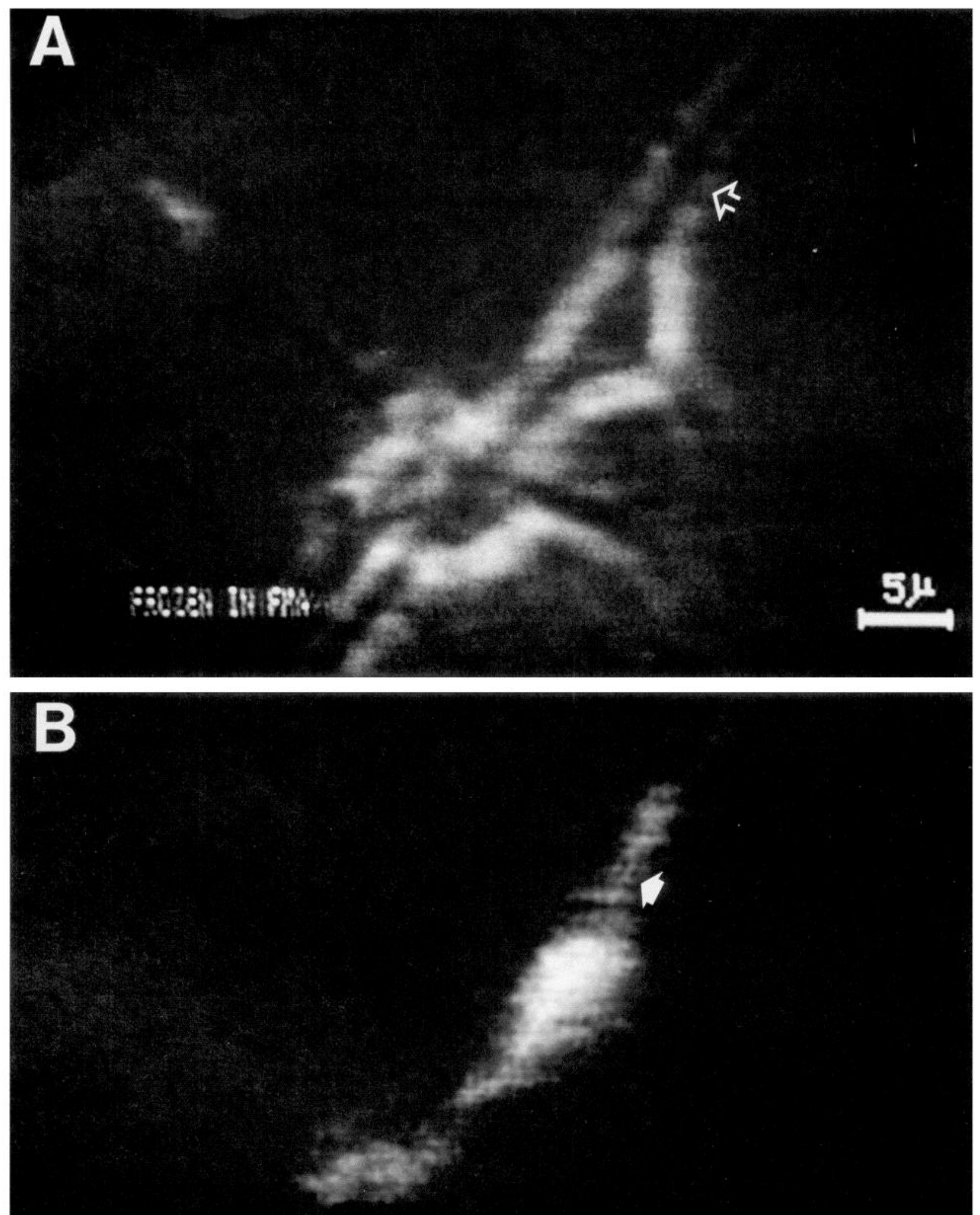

Figure 6. Fluorescence labeling of spinal cord neuronal processes by BODIPY-strychnine. Cells were labeled as described in Figure 5 and in Materials and Methods, but using BODIPY-strychnine at a final concentration of $2 \mathrm{~nm}$. $A$, Phase-contrast image of the cells; $B$, fluorescence image of the same cells. This fluorescence image was accumulated for $25 \mathrm{sec}$. The process of the cell is indicated by an open arrow in the phase image and by a solid arrow in the fluorescence image. 


\begin{tabular}{llllll}
\hline $\begin{array}{l}\text { Table 1. Diffusion coefficient (D) and mobile fraction }(f) \text { of fluorescently labeled membrane } \\
\text { components }\end{array}$ & \multicolumn{4}{c}{ ( } \\
$\begin{array}{lllll}\text { Membrane } \\
\text { component }\end{array}$ & Probe & Region & $10^{-9} \mathrm{~cm}^{2} / \mathrm{sec}$ & $f \pm\langle f\rangle$ & $n^{\alpha}$ \\
\hline Glycine receptor & BODIPY-strychnine & Soma & $1.15 \pm 0.05$ & $0.48 \pm 0.17$ & 51 \\
& & Process & $0.55 \pm 0.07$ & $0.29 \pm 0.09$ & 25 \\
Glycoprotein & TmRhd-WGA & Soma & $0.45 \pm 0.05$ & $0.45 \pm 0.09$ & 10 \\
& & Process & $0.40 \pm 0.03$ & $0.40 \pm 0.07$ & 10 \\
Phospholipid & TmRhd-PE & Soma & $7.24 \pm 0.06$ & $1.07 \pm 0.08$ & 20 \\
& & Process & $7.03 \pm 0.05$ & $1.0 \pm 0.03$ & 20 \\
\hline
\end{tabular}

a Number of experiments.

neurons with $K_{i}$ 's of 15 and 20 nM. In control experiments, we verified that the fluorescent moiety itself did not displace ${ }^{3} \mathrm{H}$ strychnine. Thus, NBD-hexanoic acid or BODIPY-acetic acid at concentrations of $0.1 \mathrm{~mm}$ have no effect on the binding of ${ }^{3} \mathrm{H}$-strychnine to spinal cord membranes (data not shown). The density of ${ }^{3} \mathrm{H}$-strychnine binding sites on membranes prepared from rat spinal cord cultures was $1.25 \mathrm{pmol} / \mathrm{mg}$, which corresponds to $\sim 2.5 \times 10^{5}$ receptors per cell assuming a homogeneous distribution. The higher density of ${ }^{3} \mathrm{H}$-strychnine binding sites that we obtain in these cultures compared with a recent study (Hoch et al., 1989) may be related to the differences in the spinal cord neuron cultures. In our cultures, horse serum, nerve growth factor, or antibiotics were not added and dorsal root ganglion neurons are clearly absent.

Because of its superior spectroscopic properties and greater resistance to photobleaching than NBD-strychnine, BODIPYstrychnine was selected for fluorescence digital imaging and FPR studies, although these 2 ligands interact at exactly the same receptor site. Figure $5, B-D$, shows the labeling of spinal cord neurons in culture with $10 \mathrm{nM}$ BODIPY-strychnine. Figure 5.1 is the phase image of the cells; panel $B$ shows the fluorescence image of cells labeled with $10 \mathrm{~nm}$ BODIPY-strychnine and represents both the specific and nonspecific fluorescence signal; panel $C$ is the same field after incubation with $100 \mu \mathrm{M}$ strychnine nitrate and represents the nonspecific component of the labeling. The nonspecific labeling is very low and, by comparison with the numerical values of the digitized images, is $\sim 10 \%$ of total binding. Because the images in Figure $5, B, C$, are of the same identical field, with no changes in optical conditions, each pixel of the nonspecific image in panel $C$ was subtracted from panel $B$ to yield values of the specific image (panel $D$ ). To aid in visual representation, the intensity levels ( 256 gray levels) have been displayed in color, where white represents the most intensely labeled regions of the neuron. As seen in Figure $5, B, D$, the neuronal cell body is intensely labeled with BODIPY-strychnine. Because of the high concentration of GlyR and intense fluorescence signal on the cell body, the dynamic range of the ultrasensitive photon-counting camera is easily exceeded; thus, even though GlyRs are present on processes, but at reduced numbers relative to the cell body, in these images fluorescence on the processes is low and appears to have escaped detection. In addition, fluorescence on processes appears even lower because of the small diameter of the processes relative to the size of the imaging pixel (and thus the lower probability of photon capture). However, when labeling of cells is carried out with subsaturating concentrations of ligand, so that not all cell body receptors are occupied, images can be accumulated for longer times and labeling on processes can be clearly seen (Fig. 6, $A$,
$B$ ). A neuronal process (indicated by the open arrow in the phase image of panel $A$ ) is clearly labeled by BODIPY-strychnine (closed arrow, panel $B$ ).

Evaluation of the intensity levels in the fluorescence image of the neuron in Figure $5 D$ shows that even within the cell body, the distribution of GlyRs is not uniform and there are regions of high and low receptor density. This distribution pattern is different from that we have observed for other receptors. By comparison on the cell body the distribution of GABA/benzodiazepine receptors on spinal cord neurons (Velazquez et al., 1989) or fluorescently labeled $\mathrm{Ca}^{2+}$ channels on hippocampal neurons (Jones et al., 1989) are marked by multiple clusters on all bodies.

To gain insight into how GlyRs may be segregated and maintained in these regions, we measured the lateral mobility of GlyRs on the cell body and processes by FPR (Fig. 7, Table 1). We were surprised to find that even though confined to the cell body, GlyRs are very mobile, with $48 \pm 17 \%$ of the receptors able to move at rates of $1.15 \pm 0.05 \times 10^{-9} \mathrm{~cm}^{2} / \mathrm{sec}$ (Fig. $7 A$ ), a value close to that of unrestricted protein movement through a lipid bilayer. However, the remaining fraction of GlyRs, 52\%, are indeed immobile on the time scale of this experiment, suggesting an immobilization by intra- or extracellular elements (Fig. 7). On processes (Fig. $7 D$ ), the recovery was considerably lower, $29 \pm 9 \%$. The diffusion rate of $5.53 \pm 0.07 \times 10^{-10} \mathrm{~cm}^{2} /$ sec was much slower than on the cell body, and more typical of most membrane glycoproteins. The low fractional mobility or diffusion rate is not due to diffusion into a limited membrane area because the membrane area of the processes is 2 times larger than the diameter of the spot photobleached (Angelides et al., 1988). While the distribution and mobility of GlyRs on the cell body and processes are different, the mobility of TmRhwheat germ agglutinin (TmRhd-WGA) and TmRhd-phosphatidyl-ethanolamine (TmRhd-PE) are similar in each region of the neuron examined (Fig. 7, $B$ and $E, C$ and $F$, respectively). The lateral mobility of TmRhd-WGA receptors on the cell body and processes is $4.50 \pm 0.05 \times 10^{-10} \mathrm{~cm}^{2} / \mathrm{sec}(f=0.45$; SD $n$ $=10)$ and $4.00 \pm 0.03 \times 10^{-10} \mathrm{~cm}^{2} / \mathrm{sec}(f=0.40 ; \operatorname{SD} n=10)$, respectively. The lateral mobility of $\mathrm{TmRhd-PE}$ on the cell bodies and processes is $7.24 \pm 0.06 \times 10^{-9} \mathrm{~cm}^{2} / \mathrm{sec}(f=1.07 ; \mathrm{SD}$ $n=20)$, and $7.03 \pm 0.05 \times 10^{-9} \mathrm{~cm}^{2} / \mathrm{sec}(f=1.0 ; \operatorname{SD} n=20)$, respectively.

For comparison on the cell body, $>80 \%$ of the $\mathrm{GABA}_{\mathrm{A}}$ receptors (Velazquez et al., 1989) and voltage-dependent $\mathrm{Ca}^{2+}$ channels (Jones et al., 1989) are immobile $\left(D_{\mathrm{L}}<10^{-12} \mathrm{~cm}^{2} /\right.$ sec). The mobility of GlyRs on the cell body is similar to the lateral mobility of voltage-dependent sodium channels whose rates of lateral diffusion on the cell body are $2 \times 10^{-9} \mathrm{~cm}^{2} / \mathrm{sec}$. 


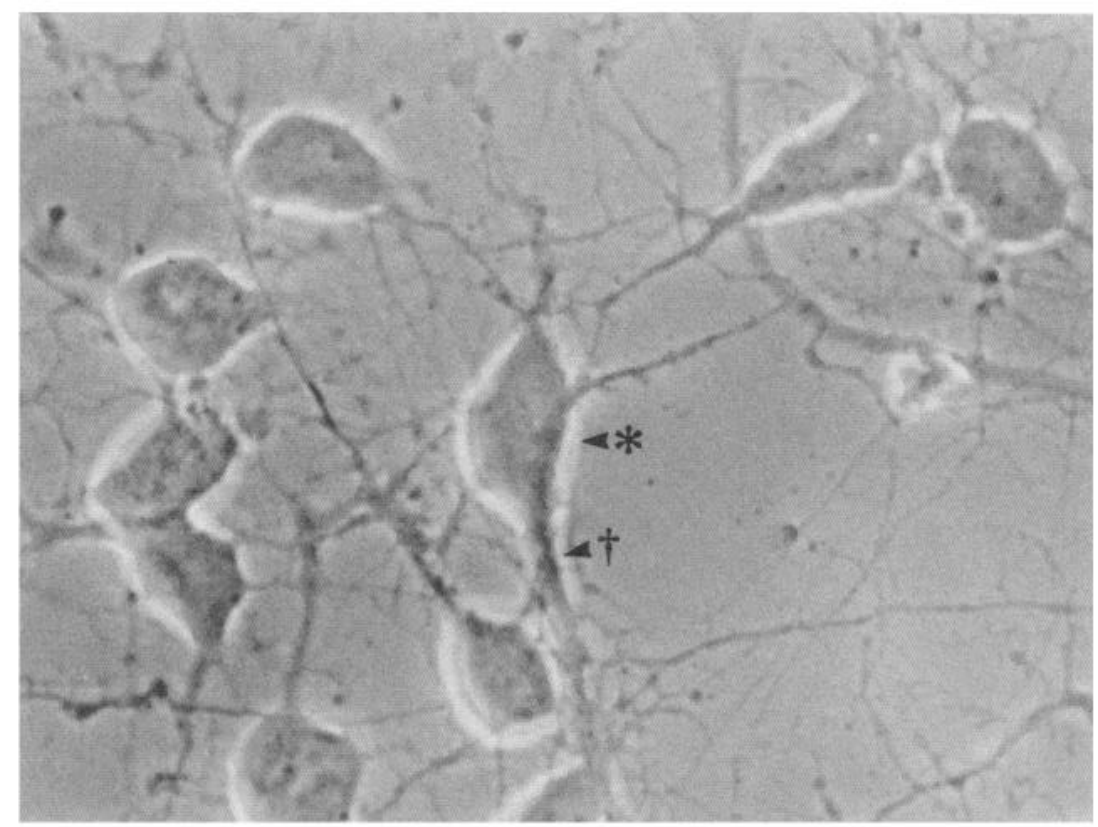

\section{CELL BODY (*)}

A.

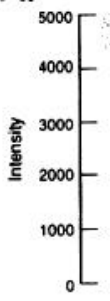

B.

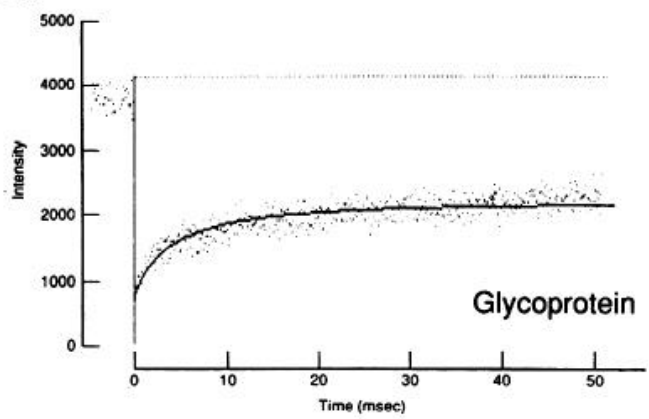

C.

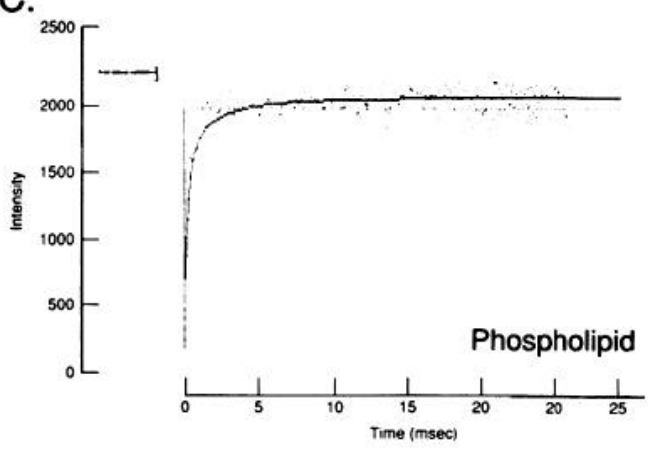

PROCESS (†)

D.

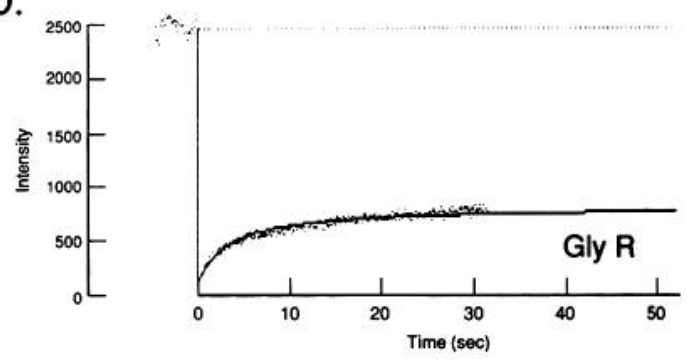

E.

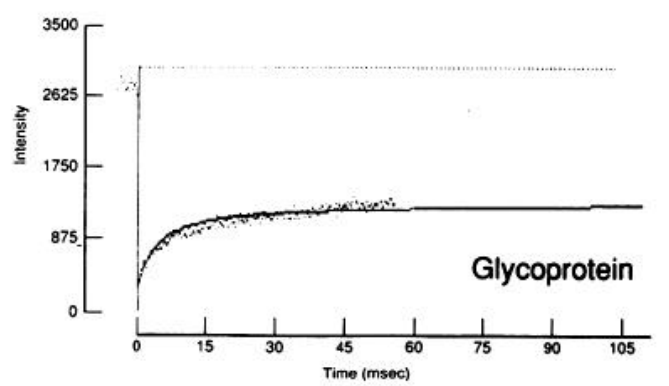

F.

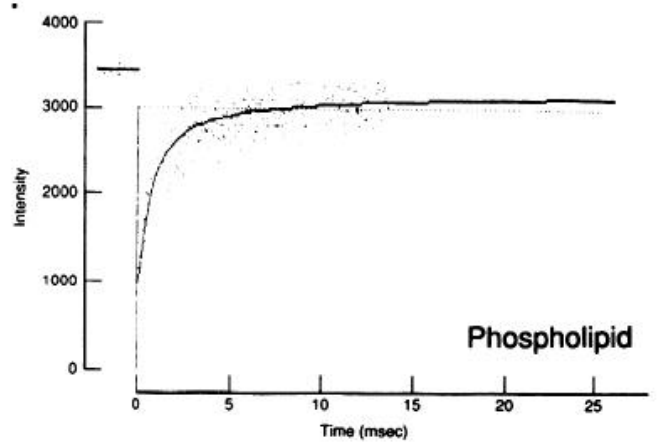




\section{Discussion}

In the present study we have developed 2 fluorescent strychnine analogs to study the distribution and lateral mobility of GlyRs on cultured spinal cord neurons. Non-amino acid agonists of the glycine receptor have not been found, and because of its high endogenous levels in neural tissue, low affinity, and structural limitations, glycine is an unsuitable ligand for studies of receptor distribution. The high affinity and well-characterized specificity of strychnine for GlyRs, as well as the ability to modify the aromatic ring without the loss of activity, makes strychnine an ideal antagonist ligand to study the dynamics of GlyR topography in adult tissue and in tissue culture.

Previous studies on the distribution of GlyRs in various regions of the brain have primarily utilized 2 techniques: (1) direct autoradiography using ${ }^{3} \mathrm{H}$-glycine (Bristow et al., 1986) or ${ }^{3} \mathrm{H}$ strychnine (Zarbin et al., 1981; Probst et al., 1986); and (2) immunohistochemical techniques using glycine-specific antibodies (van den Pol and Gorcs, 1988) or mAbs to the 93 or $48 \mathrm{kDa}$ GlyR subunits (Triller ct al., 1985; Araki et al., 1988). Although these studies have provided very useful information on receptor distribution in the central and peripheral nervous systems, they present only a static view of GlyR topography. In addition, some of these techniques also have inherent deficiencies. For example, the limitations of autoradiography render it difficult to assess the precise distribution of labeled receptor molecules with respect to the plasma membrane (Zarbin et al., 1986). The use of antibodies against glycine itself cannot discriminate between glycine located at inhibitory strychnine-sensitive GlyRs and glycine associated with strychnine-insensitive receptors, such as those involved in $N$-methyl-D-aspartate channel activation (Johnson and Asher, 1987; Bertolino and Vicini, 1988).

To date the most direct and convincing information on GlyR distribution has been provided by using mAbs to the $93 \mathrm{kDa}$ cytoplasmically oriented component of the GlyR and the 48 $\mathrm{kDa}$ strychnine binding peptide (Graham et al., 1885). Immunofluorescence microscopy using monoclonal anti-93 and 48 $\mathrm{kDa}$ antibodies has shown that in rat ventral horn fibers, GlyRs are concentrated in patches of high density on the cell soma with sparser labeling on dendritic regions (Triller et al., 1985). Moreover, ultrastructural analysis of GlyRs in these fibers has shown that these patches are closely apposed to presynaptic active zones (Triller et al., 1985). Similar studies on the Mauthner cell of the goldfish (Seitanidou et al., 1988) and in the ventral cochlear nucleus (Altschuler et al., 1986) using anti-93 and 48 kDa GlyR antibodies also demonstrate a similar topography of GlyRs on cell bodies and dendrites. However, on cerebellar Purkinje cells, GlyRs are primarily localized and segregated to dendrites (Triller et al., 1987). Such differences in GlyR distribution between neurons in the spinal cord and cerebellum are likely related to the differences in physiological functions executed by these neurons. The segregation of GlyRs predominantly to cell soma in our studies of living spinal neurons is consistent with the localization of these receptors on cell bodies of spinal cord tissue sections (Triller et al., 1985). In addition, the localization of GlyRs on cell bodies is also consistent with the scnsitivity of $\mathrm{Cl}^{-}$conductances to glycine on cell bodies measured by electrophysiological means that have been reported earlier (Peacock et al., 1973; Jackson et al., 1982).

We also observed that this perikaryal localization of GlyRs is present without any observable contact by other neuronal processes, suggesting that segregation of GlyRs to the cell body does not require synaptic contact. Previous electrophysiological studies (Jackson et al., 1982) also support this observation where inhibitory conductances are expressed on cell bodies prior to contact. In other studies we have reported that $\mathrm{GABA}_{\mathrm{A}}$ receptors and voltage-dependent $\mathrm{Ca}^{2+}$ channels exist as multiple clusters even in the absence of observable contact; however, for the latter these clusters appear to redistribute upon synaptic contact (Jones et al., 1989). On the other hand, in these same neurons on the cell body voltage-dependent $\mathrm{Na}^{+}$channels always remain sparsely and diffusely distributed (Angelides et al., 1988). Although in our studies GlyRs and $\mathrm{GABA}_{\mathrm{A}}$ receptors assume different distribution patterns, there is some suggestion from patch-clamp studies (Hamill et al., 1983) that GABA and GlyRs coexist within a 5-20 $\mu \mathrm{m}$ area of the cell body membrane and that GABAergic presynaptic terminals (identified immunocytochemically by antiglutamic acid decarboxylase staining) are in direct opposition to GlyR on the postsynaptic membrane (Triller et al., 1987). Given the rapid mobility of GlyRs on the cell body, this co-localization of GABA $\mathrm{A}_{\mathrm{A}}$ and GlyRs could arise from the rapid redistribution of GlyRs during patch-clamp recordings. More recently, the rapid redistribution of cell surface receptors could confer additional plasticity to the neuron because the same or similar channel protein could be complexed with different agonist recognition sites to form a family of associated receptor-ionophore complexes (Linn-Pfeiffer and Glantz, 1989).

That GlyRs are segregated and confined within the neuronal cell body is surprising in view of the fact that a large fraction of GlyRs are freely mobile on the cell body. The lateral mobility of GlyR on the cell body is at the very high range for membrane proteins. In comparison with the measurements of TmRhd-PE, mobile GlyRs on the cell body diffuse at rates close to those expected for membrane proteins limited only by the viscosity of the lipid bilayer. Given such rapid lateral diffusion rates, we would expect GlyRs to assume a random distribution on the cell surface. Indeed, for other ion channel/receptors that demonstrate rapid mobility the distribution is diffuse and homogeneous on the cell surface, e.g., voltage-dependent $\mathrm{Na}^{+}$channels (Angelides et al., 1988), the ACh receptor in embryonic muscle (Poo, 1982), rhodopsin in amphibian ROD outer segment disks (Poo and Cone, 1974), for some cell surface antigens such as PT-1 (Myles et al., 1984), and for plasma membrane proteins where the underlying cytoskeleton has been separated from the membrane (Tank et al., 1982).

There are several possibilities that could account for the free mobility yet restricted localization of GlyRs on the cell body.

\footnotetext{
Figure 7. Representative fluorescence photobleach recovery curves on spinal cord neurons ( 3 weeks in culture). The FPR curves were obtained at locations indicated by an asterisk on the cell body and by a dagger on the process of a representative cell shown in the the phase-contrast micrograph. Curves in $A$ and $D$ were obtained using BODIPY-strychnine (10 nM final concentration). $B$ and $E$ represent labeling of cells using a glycoprotein probe TmRh-WGA ( $20 \mathrm{~nm}$ final concentration) and $C$ and $F$, labeling with a lipid probe TmRh-PE (30 nM final concentration). Experimental details are described in Materials and Methods. Data from these experiments are summarized in Table 1.
} 
(1) GlyRs could form transient associations with the underlying cytoskeleton in the cell body. An example of this kind of interaction occurs in red blood cells, where a fraction of Band 3 molecules are freely mobile on the FPR time scale (Cherry, 1979). Because such associations would be weak associations that form on the time scale of the FPR experiments (sec), the steady-state distribution of GlyRs would appear homogeneous. (2) GlyRs might interact sterically with other proteins which are present at high concentrations in the plasma membrane. However, this kind of interaction typically seems to have only a weak effect on membrane protein diffusion (Small et al., 1984). (3) GlyR could be confined within a domain or barrier established hy the underlying cytoskeletal meshwork (Koppel et al., 1981). This type of restriction in distribution has been described for proteins of the red blood cell and sperm cell membranes (Cowan et al., 1987), as well as for rhodopsin in amphibian rod outer segment disks (Poo and Cone, 1974). GlyRs in this model would be free to diffuse within the macroscopic domains $(1-2 \mu \mathrm{m})$ measured by FPR, yet encounter barriers of dimensions 3-10 $\mu \mathrm{m}$ which would restrict their entry into other regions of the cell. Clustering of GlyRs could arise in principle by diffusionmediated trapping where mobile GlyRs are trapped within the boundaries established by either extra- or intracellular matrix (Koppel et al., 1981; Cowan et al., 1987). FPR measurements using successive bleaches deplete the fluorescence signal and suggest that an impermeable barrier between the cell body and processes could prevent redistribution of GlyRs between regions (without limiting their diffusion within the region). Additional examples of such selective and long-range barriers to diffusion come from studies of the PT-1 antigen on sperm cells, which is confined to, but diffuses freely in, the posterior tail region (Myles et al., 1984), and of voltage-dependent $\mathrm{Na}^{+}$channels, where the soma-hillock annulus imposes a barrier to the diffusion of specific proteins such as $\mathrm{Na}^{+}$channels while allowing other proteins and lipids to diffuse freely between these regions. This interpretation is consistent with our observation that free diffusion and exchange of GlyRs between cell soma and processes is impaired, suggesting a physical barrier, like a corral, which restricts free exchange of GlyRs between these 2 regions.

In all cells measured, there is a fraction of GlyRs which is immobile on the cell body. These receptors could be restricted by associations with the extra- or intracellular matrix or through their associations with a membrane protein, which is in turn linked to these elements. There is increasing evidence to indicate that ion channels, receptors, and membrane proteins form specific associations with cytoskeletal proteins (Edelstein et al., 1988; Godfrey et al., 1988; Srinivasan et al., 1988; Treharne et al., 1988 ) and that these associations could enable the receptors to be maintained at high densities in certain regions of the cell. For example, a $43 \mathrm{kDa}$ polypeptide has becn shown to colocalize with AChR clusters at muscle endplates (Burden, 1985; Bloch and Froehner, 1987) and ankyrin associates and co-localizes with voltage-dependent $\mathrm{Na}^{+}$channels in rat brain (Srinivasan et al., 1988) and at the neuromuscular junction (Flucher and Daniels, 1989).

The cytoplasmically located $93 \mathrm{kD}$ polypeptide of the GlyR is a potential candidate to mediate such an interaction. This protein may link GlyRs to the neuronal cytoskeleton either directly or via an intermediate such as brain ankyrin and regulate GlyR distribution and mobility. In this connection, differences in the cytoplasmic distribution of $\alpha \gamma$ (fodrin) and $\alpha \beta$ neuronal spectrins may be pertinent and contribute to the seg- regation and immobility of GlyRs on the neuronal cell surface (Lazarides and Nelson, 1985; Reiderer et al., 1985).

In addition, the possibility of the existence of distinct receptor subtypes (Akagi and Miledi, 1988) and the regulated expression of the 48 and $58 \mathrm{kDa}$ subunits and $93 \mathrm{kDa}$ component during neuronal maturation (Becker et al., 1988; Hoch et al., 1989) could greatly expand the neuron's ability to regulate GlyR distribution and mobility.

\section{References}

Akagi, H., and R. Miledi (1988) Heterogeneity of glycine receptors and their messenger RNAs in rat brain and spinal cord. Science 242: 270-273.

Altschuler, R. A., H. Betz, M. H. Parakkal, K. Reeks, and R. J. Wenthold (1986) Identification of glycinergic synapses in the cochlear nucleus through immunocytochemical localization of the postsynaptic receptor. Brain Res. 369: 316-320.

Angelides, K. J., L. W. Elmer, D. Loftus, and E. Elson (1988) Distribution and lateral mobility of voltage-dependent sodium channels in neurons. J. Cell Biol. 106: 1911-1925.

Araki, T., M. Yamano, T. Murakami, A. Wanaka, H. Betz, and M. Tohyama (1988) Localization of glycine receptors in the rat central nervous system: An immunocytochemical analysis using monoclonal antibody. Neuroscience 25: 613-624.

Axelrod, D., D. E. Koppel, J. Schlessinger, E. Elson, and W. W. Webb (1976) Mobility measurement by analysis of fluorescence photobleaching recovery kinetics. Biophys. J. 16: 1055-1069.

Becker, C.-M., W. Hoch, and H. Betz (1988) Glycine receptor heterogeneity in rat spinal cord during post-natal development. EMBO J. 7: 3717-3726

Bertolino, M., and S. Vicini (1988) Voltage-dependent block by strychnine of $\mathrm{N}$-methyl D-aspartic acid activated cationic channels in rat cortical neurons in culture. Mol. Pharmacol. 34: 98-103.

Bloch, R. J., and S. C. Froehner (1987) The relationship of the postsynaptic $43 \mathrm{~K}$ protein to acetylcholine receptors in receptor clusters isolated from cultured rat myotubules. J. Cell Biol. 104: 645-654.

Bottenstein, J. E., and G. H. Sato (1979) Growth of a rat neuroblastoma cell line in serum-free supplemented medium. Proc. Natl. Acad. Sci. USA 76: 514-517.

Bradford, M. M. (1976) A rapid and sensitive method for the quantitation of microgram quantities of protein utilizing the principle of protein-dye binding. Anal. Biochem. 72: 248-254.

Bristow, D. R., N. G. Bowery, and G. N. Woodruff (1986) Light microscopic autoradiographic localization of ${ }^{3} \mathrm{H}$ glycine and ${ }^{3} \mathrm{H}$ strychnine binding sites in rat brain. Eur. J. Pharmacol. 126: 303307.

Burden, S. J. (1985) The subsynaptic $43 \mathrm{kDa}$ protein is concentrated at developing nerve muscle synapses in vitro. Proc. Natl. Acad. Sci. USA 82: 8270-8273.

Cheng, Y. C., and W. H. Prusoff (1973) Relationship between inhibition constant $\left(\mathrm{K}_{\mathrm{i}}\right)$ and the concentration of inhibitor which causes $50 \%$ inhibition $\left(\mathrm{I}_{50}\right)$ of an enzymatic reaction. Biochem. Pharmacol. 22: 3099-3108.

Cherry, R. J. (1979) Rotational and lateral diffusion of membrane proteins. Biochem. Biophys. Acta 559: 289-327.

Coombs, J. S., J. C. Eccles, and P. Fatt (1955) The specific ionic conductances and the ionic movements across the motoneuronal membrane that produce the inhibitory post-synaptic potential. $J$. Physiol. (Lond.) 130: 326-373.

Cowan, A. E., D. G. Myles, and D. E. Koppel (1987) Lateral diffusion of the PH-20 protein on guinea pig sperm: Evidence that barriers to diffusion maintain plasma membrane domains in mammalian sperm. J. Cell Biol. 104: 917-923.

Edelstein, N. G., W. A. Catterall, and R. T. Moon (1988) Identification of a 33-kilodalton cytoskeletal protein with high affinity for the sodium channel. Biochemistry 27: 1818-1822.

Flucher, B. E., and M. P. Daniels (1989) Distribution of $\mathrm{Na}^{+}$channels and ankyrin in neuromuscular junctions is complementary to that of acetylcholine receptors and the $43 \mathrm{kDa}$ protein. Neuron 3: 163-175.

Godfrey, E. W., M. E. Dietz, A. L. Morstad, P. A. Wallskog, and D. E. Yorde (1988) Acetylcholine receptor-aggregating proteins are associated with the extracellular matrix of many tissues in Torpedo. $J$. Cell Biol. 106: 1263-1272. 
Graham, D., F. Pfeiffer, and H. Betz (1981) UV light-induced crosslinking of strychnine to the glycine receptor of rat spinal cord membranes. Biochem. Biophys. Res. Commun. 102: 1330-1335.

Graham, D., F. Pfeiffer, R. Simler, and H. Betz (1985). Purification and characterization of the glycine receptor of pig spinal cord. Biochemistry 24: 990-994.

Grenningloh, G., A. Rienitz, B. Schmitt, C. Methfessel, M. Zensen, K. Beyreuther, E. D. Gundelfunger, and H. Betz (1987) The strychninebinding subunit of the glycine receptor shows homology with nicotinic acetylcholine receptors. Nature 328: 215-220.

Hamill, O. P., J. Borman, and B. Sakman (1983) Activation of multiple conductance state chloride channels in spinal neurons by glycine and GABA. Nature 305: 805-808.

Haugland, R. P., and H. C. Kang (1988) U.S. patent number: 4774339.

Henis, Y. I., and E. L. Elson (1981) Inhibition of the mobility of mouse lymphocyte surface immunoglobulins by locally bound concanavalin A. Proc. Natl. Acad. Sci. USA 78: 1072-1076.

Hoch, W. H. Betz, and C. M. Becker (1989) Primary cultures of mouse spinal cord express the neonatal form of the inhibitory glycine receptor. Neuron 3: 339-349.

Jackson, M. B., H. Lecar, D. E. Brenneman, S. Fitzgerald, and P. G. Nelson (1982) Electrical development in spinal cord cell cultures. J. Neurosci. 2: 1052-1061.

Johnson, J. W., and P. Ascher (1987) Glycine potentiates the NMDA response in cultured mouse brain neurons. Nature 325: 529-531.

Jones, O. T., D. L. Kunze, and K. J. Angelides (1989) Localization and mobility of $\omega$-conotoxin-sensitive $\mathrm{Ca}^{2+}$ channels in hippocampal CA1 neurons. Science 244: 1189-1193.

Koppel, D. E, M. P. Sheetz, and M. Schindler (1981) Matrix control of protein diffusion in biological membranes. Proc. Natl. Acad. Sci. USA 78: 3576-3580.

Krnjevic, K. (1974) Chemical nature of synaptic transmission in vertebrates. Physiol. Rev. 54: 418-540.

Lazarides, E., and J. W. Nelson (1985) Expression and assembly of the erythroid membrane skeletal proteins ankyrin (goblin) and spectrin in the morphogenesis of chicken neurons. J. Cell. Biochem. 27: 423-441.

Linn-Pfeiffer, C., and R. M. Glantz (1989) Acetylcholine and GABA mediate opposing actions on neuronal chloride channels in crayfish. Science 245: 1249-1251.

Mackerer, C. R., R. L. Kochman, T. F. Shen, and F. M. Hershenson (1977) The binding of strychnine and strychnine analogs to synaptic membranes of rat brainstem and spinal cord. J. Pharmacol. Exp. Ther. 201: 326-331.

Myles, D. G., P. Primakoff, and D. E. Koppel (1984) A localized surface protein of guinea pig sperm exhibits free-diffusion in its domain. J. Cell Biol. 98: 1905-1909.

Nelson, P. G. (1976) Central nervous system synapses in cell culture. Cold Spring Harbor Symp. Quant. Biol. 40: 359-371.

Nelson, P. G., B. R. Ransom, M. Henkart, and P. N. Bullock (1977) Mouse spinal cord in cell culture. IV. Modulation of inhibitory synaptic function. J. Neurophysiol. 40: 1178-1187.

Peacock, J. H., P. G. Nelson, and M. W. Goldstone (1973) Electrophysiological study of cultured neurons dissociated from spinal cord and dorsal root ganglia of fetal mice. Dev. Biol. 30: 137-152.

Pfeiffer, F., D. Graham, and H. Betz (1982) Purification by affinity chromatography of the glycine receptor of rat spinal cord. J. Biol. Chem. 257: 9389-9393.
Poo, M. M. (1982) Rapid lateral diffusion of functional Ach receptors in embryonic muscle cell membrane. Nature 295: 332-335.

Poo, M. M., and R. A. Cone (1974) Lateral diffusion of rhodopsin in the photoreceptor membrane. Nature 247: 438-441.

Probst, A., R. Cortes, and J. M. Palacios (1986) The distribution of glycine receptors in the human brain. A light microscopic autoradiographic study using $\left[{ }^{3} \mathrm{H}\right]$ strychnine. Neuroscience $17: 11-35$.

Reiderer, B. M., I. S. Zagon, and S. R. Goodman (1985) Brain spectrin (240/235) and brain spectrin (240/235E): Two distinct spectrin subtypes with different locations within mammalian neural cells. J. Cell Biol. 102: 2088-2097.

Rosenmund, P. (1961) Synthesis of 2-diazostrychnine. Chem. Ber. 94: $3342-3345$.

Schmieden, V., G. Grenningloh, P. R. Schofield, and H. Betz (1989) Functional expression in Xenopus oocytes of the strychnine binding $48 \mathrm{kD}$ subunit of the glycine receptor. EMBO J. 8: 695-700.

Schmitt, B., P. Knaus, C-M. Becker, and H. Betz (1987) The Mr 93,000 polypeptide of the postsynaptic glycine receptor complex is a peripheral membrane protein. Biochemistry 26: 805-811.

Seitanidou, T., A. Triller, and H. Korn (1988) Distribution of glycine receptors on the membrane of a central neuron: An immunoelectron microscopic study. J. Neurosci. 8: 4319-4333.

Small, R. K., M. Blank, R. Ghez, and K. H. Pfenninger (1984) Components of the plasma membrane of growing axons. II. Diffusion of membrane protein complexes. J. Cell Biol. 98: 1434-1443.

Snyder, S. H., and J. P. Bennett (1976) Neurotransmitter receptors in the brain: Biochemical identification. Annu. Rev. Physiol. 38: 153175

Srinivasan, Y., L. Elmer, J. Davis, V. Bennett, and K. J. Angelides (1988) Ankyrin and spectrin associate with voltage-dependent sodium channels in brain. Nature 333: 177-180.

Tank, D. W., E. S. Wu, and W. W. Webb (1982) Enhanced molecular diffusibility in muscle membrane blebs: Release of lateral constraints J. Cell Biol. 92: 207-212.

Treharne, K. J., D. Rayner, and A. J. Baines (1988) Identification and partial purification of ABGP205, an integral membrane glycoprotein from brain that binds ankyrin. Biochem. J. 253: 345-350.

Triller, A., F. Cluzeaud, F. Pfeiffer, H. Betz, and H. Korn (1985) Distribution of glycine receptors at central synapses: An immunoelectron microscopy study. J. Cell Biol. 101: 683-688.

Triller, A., F. Cluzeaud, and H. Korn (1987) Gamma-aminobutyric acid-containing terminals can be opposed to glycine receptors at central synapses. J. Cell Biol. 104: 947-956.

van den Pol, A., and T. Gorcs (1988) Glycine and glycine receptor immunoreactivity in brain and spinal cord. J. Neurosci. 8: 472-492.

Velazquez, J. L., C. L. Thompson, E. M. Barnes, and K. J. Angelides (1989) Distribution and lateral mobility of GABA/benzodiazepine receptors on nerve cells. J. Neurosci. 9: 2163-2169.

Young, A. B., and S. H. Snyder (1973) Strychnine binding associated with glycine receptors of the central nervous system. Proc. Natl. Acad. Sci. USA 70: 2832-2836.

Zarbin, M. A., J. K. Wamsley, and M. J. Kuhar (1981) Glycine receptor light microscopic autoradiographic localization with $\left[{ }^{3} \mathrm{H}\right]$ strychnine. J. Neurosci. I: 532-547.

Zarbin, M. A., J. K. Wamsley, J. M. Palacios, and M. J. Kuhar (1986) Autoradiographic localization of high-affinity GABA, benzodiazepine dopaminergic, adrenergic and muscarinic cholinergic receptors in the rat, monkey and human retina. Brain Res. 374: 75-92. 